\title{
Validation of EST-derived microsatellite markers for two Cerrado-endemic Campomanesia (Myrtaceae) species
}

\author{
E.A.G.C. Miranda' ${ }^{1}$, C.R.D. Boaventura-Novaes ${ }^{2}$, R.S. Braga' ${ }^{1}$, E.F. Reis ${ }^{3}$, \\ J.F.N. Pinto ${ }^{3}$ and M.P.C. Telles ${ }^{1}$ \\ ${ }^{1}$ Laboratório de Genética \& Biodiversidade, Departamento de Genética, \\ Instituto de Ciências Biológicas, Universidade Federal de Goiás, Goiânia, GO, Brasil \\ 2Programa de Pós-Graduação em Genética e Melhoramento de Plantas, \\ Escola de Agronomia, Universidade Federal de Goiás, Goiânia, GO, Brasil \\ ${ }^{3}$ Programa de Pós-Graduação em Agronomia, Universidade Federal de Goiás, \\ Jataí, GO, Brasil \\ Corresponding author: M.P.C. Telles \\ E-mail: tellesmpc@gmail.com \\ Genet. Mol. Res. 15 (1): gmr.15017658 \\ Received September 17, 2015 \\ Accepted December 21, 2015 \\ Published March 4, 2016 \\ DOI http://dx.doi.org/10.4238/gmr.15017658
}

\begin{abstract}
We assessed the transferability of 120 EST-derived Eucalyptus microsatellite primers to Campomanesia adamantium and $C$. pubescens. Both species are berry trees native to the Brazilian Cerrado, and population genetic information is poor. Twelve markers were used to analyze the genetic variability of four sampled populations. Regarding DNA extraction, we sampled leaf tissues from two populations of each species (80 individuals). Of the 120 primers evaluated, 87 did not amplify any PCR products, and 21 rendered nonspecific amplification. Twelve primers were successfully transferred, providing a low combined probability of genetic identity for both species $\left(5.718 \times 10^{-10}\right.$ for $C$. adamantium; $1.182 \times 10^{-11}$ for C. pubescens) and a high probability of paternity exclusion ( 0.99939 for $C$. adamantium; 0.99982 for $C$. pubescens). The average number of alleles in
\end{abstract}


the polymorphic loci was 6.8 for $C$. adamantium and 7.8 for $C$. pubescens, ranging from 2 to 16 alleles per locus. The observed heterozygosity values for C. adamantium and C. pubescens were 0.504 and 0.503 , respectively, and the expected heterozygosity values for $C$. adamantium and $C$. pubescens were 0.517 and 0.579 , respectively. The populations exhibited structured genetic variability with $\theta \mathrm{P}$ values of 0.105 for $C$. adamantium and 0.249 for $C$. pubescens. Thus, we concluded that these 12 microsatellite markers, transferred from Eucalyptus, were efficient for population genetic studies of $C$. adamantium and $C$. pubescens.

Key words: Gabiroba; Genetic diversity; SSR; Transferability

\section{INTRODUCTION}

Campomanesia adamantium O. Berg and C. pubescens DC. are two species of berry trees native to the Cerrado biome, and the genus is a member of the Myrtaceae family. Campomanesia plants are well-known berry trees whose fruits are called "gabiroba", and they are utilized by local populations as edible fresh fruits or for culinary purposes in jellies, jams, ice creams, alcoholic beverages, and folk medicines (Ferreira, 1972). The genus also has considerable economic potential regarding bioactive compounds for pharmaceutical use (Czaikoski et al., 2015).

C. adamantium has interesting traits associated with its domestication, including variation in optimum harvest and consumption times (Santos et al., 2015), seed germination, and seed storage (Dresch et al., 2013, 2014). Previous morphological and molecular analyses of genetic diversity based on random amplified polymorphic DNA were conducted using progenies of 140 trees (de Assis et al., 2013). However, little information about the genetic diversity of Campomanesia is available. Additional population genetic studies are needed to support conservation and breeding programs, particularly since genetic variability in Campomanesia and other species is quickly being lost as Cerrado degradation continues. The biome is a hotspot for biodiversity conservation (Myers et al., 2000), and it is a key target for genetic variability maintenance and the sustainable use of genetic resources.

Microsatellites are one of the most widely used molecular markers in plants (Kalia et al., 2011). However, primer development for species with little or no genomic information is expensive. The conservation of transcribed regions between species allows the transference of expressed sequence tags (ESTs) that are derived from simple sequence repeat markers with a high success rate (Kalia et al., 2011). Several microsatellites have been transferred between different genera of the Myrtaceae family (Zucchi et al., 2002; Rai et al., 2013; Ferreira-Ramos et al., 2014; Nogueira et al., 2015), and this lowered the cost required for genetic diversity estimates. Therefore, the goal of this study was to investigate the heterologous amplification of microsatellite loci developed for Eucalyptus and to test their ability to genotype $C$. adamantium and C. pubescens.

\section{MATERIAL AND METHODS}

We analyzed 80 equally distributed samples from the Goiás State populations of Mineiros 
(C. adamantium), Três Ranchos (C. adamantium), Santa Rita do Araguaia (C. pubescens), and Caiapônia (C. pubescens). Prior to the amplification of all of the collected samples, crossamplification was tested in three C. adamantium individuals using 120 EST-derived Eucalyptus primers (Grattapaglia et al., 2015) (Table 1). Genomic DNA was extracted from leaf tissue using the cetyltrimethylammonium bromide $2 \%$ protocol (Doyle and Doyle, 1987). Polymerase chain reaction (PCR) was performed in a $10-\mu \mathrm{L}$ final volume that contained $7.5 \mathrm{ng}$ template DNA, $0.22 \mu \mathrm{M}$ primers (forward + reverse), $0.23 \mu \mathrm{M}$ dNTPs, $3.25 \mathrm{mg}$ bovine serum albumin (25 $\mathrm{mg} / \mathrm{mL}), 1 \mathrm{X}$ reaction buffer $\left(10 \mathrm{mM}\right.$ Tris $-\mathrm{HCl}, \mathrm{pH} 8.3$, and $\mathrm{MgCl}_{2}$ ), and $1 \mathrm{U}$ Taq DNA polymerase. The following PCR program was used: an initial step of 5 min at $94^{\circ} \mathrm{C}$; 35 cycles of $30 \mathrm{~s}$ at $94^{\circ} \mathrm{C}, 1 \mathrm{~min}$ at $48^{\circ}$ to $62^{\circ} \mathrm{C}$ (depending on the primer), and $1 \mathrm{~min}$ at $72^{\circ} \mathrm{C}$; and a final extension at $72^{\circ} \mathrm{C}$ for $45 \mathrm{~min}$.

Polymorphisms were detected by running the samples on $6 \%$ denaturing polyacrylamide gels stained with silver nitrate. Each transferred forward primer was labeled with fluorescent dyes (5' HEX, 5' NED, or 5' 6-FAM) (Table 1). The lengths of the amplified products from the 80 samples were determined using an ABI3500 automated sequencer. Allele binning and calling were performed using Data Collection and GeneMapper 5.0 (Applied Biosystems) softwares, and null alleles were detected using MICRO-CHECKER version 2.2 (Van Oosterhout et al., 2004) software.

Analyses of genetic variability, including observed $\left(H_{\mathrm{O}}\right)$ and expected $\left(H_{\mathrm{E}}\right)$ heterozygosity values, Hardy-Weinberg equilibrium (HWE) (Nei, 1973), inbreeding coefficients (Weir and Cockerham, 1984), and linkage disequilibrium were performed using the Bonferroni correction included in the FSTAT 2.9.3.2 software (Goudet, 2001). The probability of genetic identity (I) (Paetkau et al., 1995) and the paternity exclusion probability (Q) (Weir, 1996) for each locus were estimated using the Identity 1.0 software (Wagner and Sefc, 1999).

\section{RESULTS}

Of the 120 tested primers, 87 (72.5\%) lacked amplification, 21 (17.5\%) amplified nonspecific fragments, and $12(10 \%)$ amplified clearly polymorphic alleles. The allele size of these 12 markers ranged from 199 to $384 \mathrm{bp}$, and the number of alleles ranged from 2 to 16 . In $C$. adamantium, 82 alleles were amplified, with an average of 6.8 alleles per sample. Ninety-five alleles, with an average of 7.8 per locus, were amplified for C. pubescens. Regarding genotyping, it is possible to run three multiplexed reactions with four sets of primers each (Table 1). C. adamantium and C. pubescens loci EMBRA 1364 and EMBRA 1374 and C. pubescens loci EMBRA 1335, EMBRA 2011, EMBRA 809, and EMBRA 1470 showed significant heterozygote deficiencies based on the null allele analysis.

Average $H_{E}$ and $H_{O}$ values were 0.517 and 0.504 for $C$. adamantium and 0.579 and 0.503 for $C$. pubescens, respectively. C. adamantium and C. pubescens respectively exhibited five and seven loci that were not in Hardy-Weinberg equilibrium $(P<0.05)$. The combined probability of genetic identity values were $5.718 \times 10^{-10}$ for $C$. adamantium and $1.182 \times 10^{-11}$ for $C$. pubescens. The probability of paternity exclusion values were greater than 0.999 for both species. C. adamantium and C. pubescens exhibited one and nine loci pairs that significantly deviated from linkage equilibrium $(P>0.05)$, respectively. Furthermore, populations of both species have significantly structured genetic variability $(F=0.306, \theta \mathrm{P}=0.105$ for $C$. adamantium; $F=0.422$, $\theta \mathrm{P}=0.249$ for $C$. pubescens) (Table 2). 
E.A.G.C. Miranda et al.

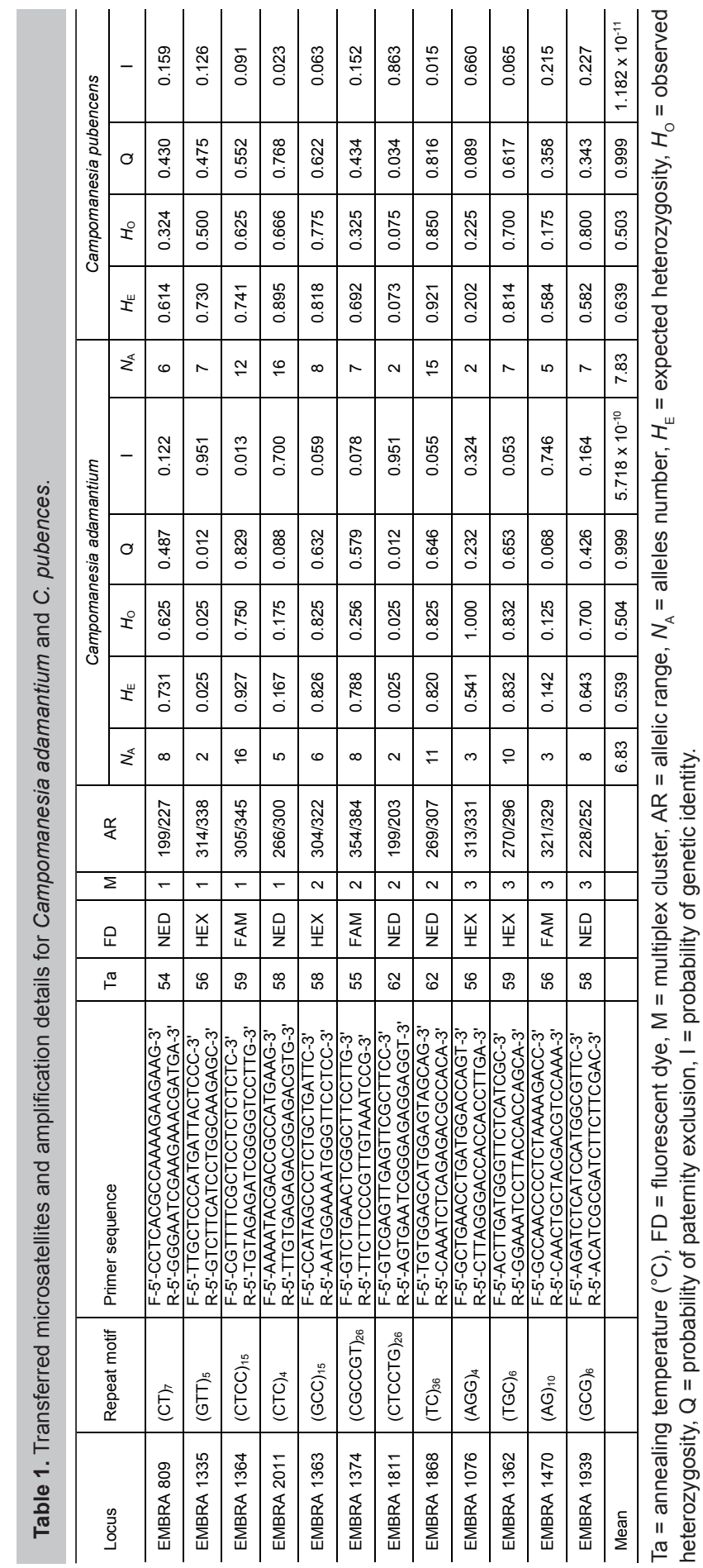


Table 2. Genetic variability estimates for four Campomanesia populations.

\begin{tabular}{|c|c|c|c|c|c|c|}
\hline & \multicolumn{6}{|c|}{ Populations } \\
\hline & Mineiros & Três Ranchos & Mean & Santa Rita do Araguaia & Caiapônia & Mean \\
\hline$N_{\mathrm{A}}$ & 5.750 & 5.250 & 5.500 & 6.500 & 5.160 & 5.830 \\
\hline$H_{E}$ & 0.531 & 0.504 & 0.517 & 0.629 & 0.529 & 0.579 \\
\hline$H_{0}$ & 0.504 & 0.505 & 0.504 & 0.498 & 0.507 & 0.503 \\
\hline \multirow[t]{2}{*}{$f$} & 0.052 & -0.002 & 0.025 & 0.213 & 0.042 & 0.138 \\
\hline & \multicolumn{3}{|c|}{ Campomanesia adamantium } & \multicolumn{3}{|c|}{ Campomanesia pubescens } \\
\hline$F$ & \multirow{2}{*}{\multicolumn{3}{|c|}{$\begin{array}{l}0.306 \\
0.105\end{array}$}} & \multirow{2}{*}{\multicolumn{3}{|c|}{$\begin{array}{l}0.422 \\
0.249\end{array}$}} \\
\hline$\theta \mathrm{P}$ & & & & & & \\
\hline
\end{tabular}

$N_{\mathrm{A}}=$ mean allele number, $H_{\mathrm{E}}=$ expected heterozygosity, $H_{\mathrm{O}}=$ observed heterozygosity, $f=$ fixation index within population, $F=$ population total fixation index, $\theta \mathrm{P}=$ genetic divergence between populations.

\section{DISCUSSION}

In general, the expected cross-amplification success rate between genera is about 10\% (Barbará et al., 2007). Therefore, our primer transfer from Eucalyptus to C. adamantium and $C$. pubescens was effective and within expectations. However, high microsatellite transferability rates (up to $40.51 \%$ ) from Psidium guajava to Campomanesia (C. guaviroba, C. hirsuta, and C. phaea) were reported (Nogueira et al., 2015). The differences in the results suggest that transferability varies between species and groups, and this is likely due to genetic proximity. The multiplexing of the 12 transferable primers into three quadruplexed reactions also saved time and resources.

The studied populations displayed significant population genetic structure, and no statistically significant inbreeding was detected. Within populations, variability accounted for the majority $(\sim 75 \%)$ of the total variation, and both species exhibited high values of $H_{0}$ and mean genetic diversity. However, higher genetic diversity was observed among C. pubescens individuals compared to $C$. adamantium individuals, and this is relevant information for the establishment of effective population conservation, management, and breeding strategies. Furthermore, the successfully transferred microsatellite loci will be useful in future population genetic studies of these and other Campomanesia species.

\section{Conflicts of interest}

The authors declare no conflict of interest.

\section{ACKNOWLEDGMENTS}

Our research program in population genetics of Cerrado plants was supported by the "Núcleo de Excelência em Genética e Conservação de Espécies do Cerrado" - GECER project (PRONEX/FAPEG/CNPq \#CP07-2009; \#CH031/2010) and by several grants and fellowships from the GENPAC ("Geographical Genetics and Regional Planning for Natural Resources in Brazilian Cerrado") research network, CNPq/MCT/CAPES/FAPEG, and the CNPq project (Proc. \#563839/2010-4). E.F. Reis and M.P.C. Telles were also supported by productivity grants from CNPq. We thank Dr. Dario Grattapaglia for kindly supplying all of the primers analyzed, Dr. Lázaro José Chaves for helping collect samples on expeditions, and Dr. Heleno Dias Ferreira for plant identification. 


\section{REFERENCES}

Barbará T, Palma-Silva C, Paggi GM, Bered F, et al. (2007). Cross-species transfer of nuclear microsatellite markers: potential and limitations. Mol. Ecol. 16: 3759-3767. http://dx.doi.org/10.1111/j.1365-294X.2007.03439.x

Czaikoski K, Mesomo MC, Krüger RL, Queiroga CL, et al. (2015). Extraction of Campomanesia xanthocarpa fruit using supercritical CO2 and bioactivity assessments. J. Supercrit. Fluids 98: 79-85. http://dx.doi.org/10.1016/j.supflu.2015.01.006

de Assis ES, Dos Reis EF, Pinto JFN, Contim LAS, et al. (2013). Genetic diversity of gabiroba based on random amplified polymorphic DNA markers and morphological characteristics. Genet. Mol. Res. 12: 3500-3509.http://dx.doi. org/10.4238/2013.March.11.7

Doyle JJ and Doyle JL (1987). A rapid DNA isolation procedure for small quantities of fresh leaf tissue. Phytochem. Bull. 19: $11-15$.

Dresch DM, Scalon SDPQ, Masetto TE and Vieira MC (2013). Germinação e vigor de sementes de gabiroba em função do tamanho do fruto e semente. Pesqui. Agropec. Trop. 43: 262-271. http://dx.doi.org/10.1590/S1983-40632013000300006

Dresch DM, Scalon SDPQ, Masetto TE and Mussury RM (2014). Storage of Campomanesia adamantium (Cambess.) $\mathrm{O}$. Berg seeds: influence of water content and environmental temperature. Am. J. Plant Sci 5: 2555-2565. http://dx.doi. org/10.4236/aips.2014.517269

Ferreira MB (1972). Frutos comestíveis nativos do D.F.: gabirobas, pitangas e araçás. 1st edn. Brasilia 4: 11-16.

Ferreira-Ramos R, Accoroni KAG, Rossi A, Guidugli MC, et al. (2014). Genetic diversity assessment for Eugenia uniflora L., E. pyriformis Cambess., E. brasiliensis Lam. and E. francavilleana O. Berg neotropical tree species (Myrtaceae) with heterologous SSR markers. Genet. Resour. Crop Evol. 61: 267-272. http://dx.doi.org/10.1007/s10722-013-0028-7

Goudet J (2001). FSTAT, a program to estimate and test gene diversities and fixation indices (version 2.9.3). Available at http:// www.unil.ch/izea/softwares/fstat.html.

Grattapaglia D, Mamani EM, Silva-Junior OB and Faria DA (2015). A novel genome-wide microsatellite resource for species of Eucalyptus with linkage-to-physical correspondence on the reference genome sequence. Mol. Ecol. Resour. 15: 437-448. http://dx.doi.org/10.1111/1755-0998.12317

Kalia RJ, Rai MK, Kalia S, Singh R, et al. (2011). Microsatellite markers: an overview of the recent progress in plants. Euphytica 177: 309-334. http://dx.doi.org/10.1007/s10681-010-0286-9

Myers N, Mittermeier RA, Mittermeier CG, da Fonseca GA, et al. (2000). Biodiversity hotspots for conservation priorities. Nature 403: 853-858. http://dx.doi.org/10.1038/35002501

Nei M (1973). Analysis of gene diversity in subdivided populations. Proc. Natl. Acad. Sci. 12: 3321-3323.

Nogueira AM, Ferreira A and Ferreira MFS (2015). Transferability of microsatellites from Psidium guajava to Eugenia, Myrciaria, Campomanesia, and Syzygium species (Myrtaceae). Plant Mol. Biol. Rep. 34: 249-256.

Paetkau D, Calvert W, Stirling I and Strobeck C (1995). Microsatellite analysis of population structure in Canadian polar bears. Mol. Ecol. 4: 347-354. http://dx.doi.org/10.1111/j.1365-294X.1995.tb00227.x

Rai MK, Phulwaria M and Shekhawat NS (2013). Transferability of simple sequence repeat (SSR) markers developed in guava (Psidium guajava L.) to four Myrtaceae species. Mol. Biol. Rep. 40: 5067-5071. http://dx.doi.org/10.1007/s11033-013$\underline{2608-1}$

Santos MA, Megguer CA, Costa AC and Lima JS (2015). Growth and development of gabiroba Campomanesia adamantium (Cambess.) O. Berg fruits. Afr. J. Agric. Res. 10: 1765-1772. http://dx.doi.org/10.5897/AJAR2014.8517

Van Oosterhout C, Hutchinson WF and Wills DPM (2004). MICRO-CHECKER: software for identifying and correcting genotyping errors in microsatellite data. Mol. Ecol. Notes 4: 535-538. http://dx.doi.org/10.1111/j.1471-8286.2004.00684.x

Wagner HW and Sefc KM (1999). Identity 1.0-Freeware program for the analysis of microsatellite data. Centre for Applied Genetics, University of Agricultural Sciences, Vienna.

Weir BS (1996). Genetic data analysis II: methods for discrete population genetic data. Sinauer Associates, Sunderland.

Weir BS and Cockerham CC (1984). Estimating F-statistics for the analysis of population structure. Evolution 38: 1358-1370. http://dx.doi.org/10.2307/2408641

Zucchi MI, Brondani RPV, Pinheiro JB, Brondani C, et al. (2002). Transferability of microsatellite markers from Eucalyptus spp. to Eugenia dysenterica (Myrtaceae family). Mol. Ecol. Notes 2: 512-513. http://dx.doi.org/10.1046/j.1471$\underline{8286.2002 .00297 . x}$ 